\title{
Modern Slavery in the UK: Hidden Behind Silence Migrant Domestic Workers in the United Kingdom Contemporary Bearings, Legal Impediments and Feasible Solutions
}

\author{
BOGÁRDI Brigitta, ${ }^{1}$ Alicia Marie FAWCETT, Jakob KRIZ
}

\begin{abstract}
Slavery, a term once used only for the past, has re-emerged in new era of globalization and transnational movement of persons across borders. Migrant domestic workers (MDWs) are immensely dependent upon the employer, which consequently creates "slavery-like" conditions for many migrant domestic workers. Using the United Kingdom as an example of migrant's rights in a developed country, we are able to view the stringent separation of migrant domestic workers' right's both nationally and internationally. Legal impediments, specifically the overseas domestic worker visa "no-change" of employer visa, thoroughly impedes the domestic workers right to change employer and thus keeps them in fear, resulting in silence. On an international basis, the United Kingdom has also not ratified the International Labour Organization Domestic Workers Convention No.189. Therefore domestic workers are not covered by its protective regulations. From analysis of data gathered during a research trip to London, this paper presents the concluding evidence of working condition problems of migrant domestic workers and provides applicable solutions for future improvement.
\end{abstract}

Keywords: migrant domestic workers, United Kingdom, modern slavery

\section{Introduction}

When the term "slavery" comes up in conversation or in textual incidences we immediately associate this concept with something that has transpired in the past. Slavery though as a concept has existed since the beginning of time.

Particularly drastic events in western history such as the Thirteenth Amendment in 1892 of the Abolishment of Slavery in the United States and the United Nations 1956 Supplementary Convention on the Abolition of Slavery movements affirmed slavery to be over. The dangers of associating the infinite and transcendent word of slavery distort distinct modern conceptual visibility in itself. Slavery in fact still exists today, only slightly shaded in the light of the market economy. The idealistic justification for a new type of slavery has emerged, a modern slavery (MS) set on the stage between the stark separation of core and peripheral countries, a place where individuals compete for the goal of self-interested sufficiency and promise of a better life. As was in the past, slavery is no longer only defined by forced labour

1 bogardi.brigitta@gmail.com 
and restricted movement. Slavery now comes in many shapes and sizes; each tailored to the global financial system. Slavery exists not only in the least developed areas, but in the most developed areas too. In many countries of Africa [1] and Asia, and in Europe too. The most aggravating thing is, that slavery does not only include adults, but even children too. In many countries of the world child slavery is a big problem. Children usually work for free, or for little payment, or as soldiers in the war-torn countries.

Many people suffer from the effects of MS, one of the most vulnerable groups is domestic workers.

"The International Labour Office (ILO) estimates that there are at least 52.6 million and perhaps as many as 100 million domestic workers worldwide. Most of these (83\%) are women, and on a global scale domestic work accounts for over $7 \%$ of all women's waged work.”[2]

Modern institutions, for instance the global financial and economic systems, both construct and generate the conditions for MS. These institutions have unlocked restraints in the movement of finances, ideas and most importantly, of persons. While institutions have been established to protect the fundamental rights of the movement of persons across borders, such as United Nations' conventions, other institutions have either been slow in response or have been bluntly unresponsive. International customary law is essential in the movement of persons and is only achievable if nation-states bind and adhere their national constitutions to international treaties for reciprocal jurisdictional action. Westerners do not typically perceive an advanced democracy, or developed country for that matter as having a problem with slavery and turn a blind eye to evident MS. Hidden behind freedom herein lays the silence of MS.

A legal framework for migrants abroad, in this case domestic workers, is compulsory in order to protect their human rights. Without these rights, the migrant domestic workers is stunned at the brink of immobility. Unsigned international treaties by states inhibit the progress of rights of MDW's. This means important treaties which protect the MDWs are not in effect in countries where the bulk of most migrants live and work. National laws, especially in developed countries, are incurably fragmented and porous. Reciprocal law action is needed to both foster the beneficial relationship between MDW's and their employers. Concomitantly, each one has the potential ability to co-exist side by side. By acknowledging the practice of modern slavery and applying laws to the MDW's situation, legal allegations and protection can be put into practice

This paper aims to addresses two dispositions: the modern definition of slavery based on the $21^{\text {st }}$ Century globalized world order and the legal ill-responsiveness of developed countries' national legislation in protecting migrant's rights. It will examine the ill-treatment of MDW in the United Kingdom (UK). This is a sector of the labour market which is not extensively researched. Our paper seeks to combine field research by conducting extensive interviews with experts and MDWs in addition to knowledge from previous studies, and connects this to information to previous studies.

In the latter, our paper will give recommendations for the United Kingdom for the protection of migrants' rights. 


\section{Historical Definition of Modern Slavery}

As citizens of the $21^{\text {st }}$ Century, we must remind ourselves of and address the issue of modern day slavery through campaigns, research and legal government support. First off, we acknowledge the current international conventions that define of MS:

- The Slavery Convention of 1926 states that "slavery is the status or condition of a person over whom any or all of the powers attaching to the right of ownership are exercised.” [3]

- International Labour Organization Forced Labour Convention (No. 29) of 1930 defines forced labour as "all work or service that is exacted from any person under the menace of any penalty for which the said person has not offered himself voluntarily." [4]

- Universal Declaration of Human Rights, 1948, says: "no one shall be held in slavery or servitude; slavery and the slave trade shall be prohibited in all their forms." [5]

- Supplementary Convention on the Abolition of Slavery, The Slave Trade, and Institutions and Practices Similar to Slavery, 1956, lists "modern forms of slavery as debt bondage, serfdom, forced marriage and the delivery of a child for the exploitation of that child are all slavery like practices and require criminalisation and abolishment.” [6]

\section{Application of Definition towards Migrant Domestic Workers}

In the $21^{\text {st }}$ Century men and women are sold as commodities with little or no legal rights and at the complete mercy of their employers. In search of a better life for their families, thousands of migrants cross borders in pursuit of work around the world. For our research purposes, we distillate domestic servitude and compare their situation to the statutory definition of contemporary MS.

Hence we define MS as:

- forced to work through mental or physical threat;

- owned or controlled by an employer, through action or threat of mental or physical abuse;

- dehumanised, treated as a commodity or bought or sold as "property";

- physically constrained or restricted freedom of movement.

The International Labour Organisation Convention on Domestic Work defines domestic work as, "work performed in or for a household or households" and domestic workers are individuals who regularly perform domestic work within an employment relationship. [7]

Some of these conditions are quite prevalently found among MDWs. The term "migrant domestic workers" refers to foreign national women and men who are brought to the UK by their employers for the purposes of working in a private household. [8] Migrant domestic workers are noted to have experienced one or many conditions of MS. The current ideas of "MS" lie on a thin line between understanding what constitutes slavery and bad working conditions. In the context of our findings, we associate Migrant Domestic Workers as immensely dependent upon the employer which consequently creates "slavery-like" conditions for MDWs. During our research we found reoccurring and consistent "slavery-like" conditions being applied to domestic workers. To conceptualize our discoveries, reoccurring problems exist for MDWs such as:

- taking of passport or working without legal documents;

- lack of educational knowledge in term of legal rights within the hosts country; 
- broken pre-arranged arrival contracts;

- working for less than the minimum wage;

- inability to work at other work if needed;

- free time; working more than 40 hours/week;

- helplessness (no acquaintances, family members or friends for assistance);

- lack of language skills of host country;

- fear of repression from host government, country's government or employers;

- house arrest (inability to leave employers' home);

- inadequate accommodation;

- unable to access medical care.

Therefore we conclude that Migrant Domestic Workers as a group are highly threatened, vulnerable, ill-treated and forced to face "slavery-like" conditions.

\section{International Legal Implications and the UK}

Upon the ending of the Cold War, the world order shifted from a bipolar to a unipolar world order, thus creating large income inequalities between developed "core" and "peripheral" countries. This immense gap, created from a mixture of globalisation and shifting economic power created a diffusion of world migration flow of migrant workers into both developed and neighbouring developing countries. [9] Legally on paper, migrants have not been held against their will, thanks to the UN Convention to Abolish Slavery since 1956, however informally these laws have not been exercised. Advanced developed countries today are still luring in migrant workers based on attractive economic gains and a possibility for a better life for their families.

The European Convention on Migrant Workers in 1977 instigated the movement for the European Union to address the rights and treatment of aliens not the territory of member states. Subsequently, it deals with the social and economic rights of workers and gives specification to some provisions of the European Social Charter (ESC). The convention was a valuable step in moving Europe into the next millennium during a time of substantial labour market migration in Europe (1966).

The judgment of the European Court of Human Rights (ECtHR) Siliadin vs. France in 2005 dealt with MS and managed to resurface old fears and helped attract great attention of international organizations, NGO's and parliamentary debates worldwide. The ECtHR recognized the extreme vulnerability and abuse suffered by migrant domestic workers, and held that this could be "forced and compulsory labour". [10] In the Siliadin case, a young migrant woman was brought to France from Togo to work and be educated, but ended up being kept in appalling "slavery-like" conditions instead.

The key elements from this case constituted the fact that she worked against her will, she was unpaid, and feared that she would be arrested. Her employers nurtured this fear and her situation was classified as servitude, because she had to work in slavery-like conditions. She worked very long hours, had no income, was vulnerable and isolated, had no private space, no free time, and no freedom of movement and no legal documents. Forced labour practices do not only exist in work such as the sex industry, they are also identified by academics as existing in key sectors of the UK labour market where workers are prone to extreme exploitation; construction; agriculture/horticulture, contract cleaning and residential care. [10] 
The ILO introduced the prohibition of forced and compulsory labour in its 1998 Declaration of Fundamental Principles and Rights at Work. [11] Yet until recently, the European legal community perceived the problem of slavery, servitude and forced and compulsory labour to be something of a reminder of the shameful past.

We also ask the question of "how does modern day legislation protect from the arising new forms of slavery”?

In contextual theory, since the signing of both the United Nations Slavery Convention in 1926 to the United Nations Declaration of Human Rights in 1948, slavery ended and individual human rights are protected regardless of citizenship, both signed by the UK. [3] Nonetheless in reality and practice, new forms of slavery were created with the help of a contemporary, globalized world. This was recognized by a high proportion of countries in the world and thus resulted in the adoption of the current ILO in 2011, and entered force in 2013. A historic adoption of international standards provided universal rights for working conditions across the world including: the right to decent work, entitlement to minimum wage and to choose the place where they live and spend their leave. [12]

The ILO recognized that, "domestic work continues to be undervalued, invisible and is mainly carried out by women and girls, many of whom are migrants or members of disadvantaged communities and who are particularly vulnerable to discrimination in respect of conditions of employment and work, and to other abuses of human rights" (Preamble of ILO Convention 189 2011). The ILO C189 Domestic Workers Convention was a remarkable leap towards abolishing slave-like conditions for migrant workers. The UK refused to sign the treaty and therefore is not obliged to adhere to international standards and rights for domestic workers.

In addition to not signing or ratifying the ILO treaty, the UK also did not sign the United Nations International Convention on the Status of Migrant Workers and their Families in 1990.

The International Convention on the Protection of the Rights of All Migrant Workers and Members of Their Families is a tool of international customary law used to define rights of migrant workers, protect workers from discrimination, and to grant equal access to the labour market. The convention was in pursuance of protection of the basic rights of migrant workers due to their increasingly vulnerable status. The preamble exposed the already conscious need to protect migrant workers from weak national legislation. This apparent necessity appears in the preamble, "convinced that the rights of migrant workers and members of their families have not been sufficiently recognized everywhere and therefore require appropriate international protection.” [12] Even more disturbing is the fact that no other Western migrant-receiving State has ratified the Convention, even though the majority of migrants live in Europe and North America.

\section{The EU and Labour Migration}

"The EU Charter of Fundamental Rights provides in Article 5 that no one shall be held in slavery or servitude, or be required to perform forced or compulsory labour.” [13]

The concept of immigration remains an important objective of current EU migration regimes. Current migration and immigration policies of the EU are simply devoid of migrants' perceptions and needs. Numerous migrants with higher education were engaged in low- 
skilled jobs or were unemployed. They report that no one was interested in their prior education, while many do not have their education recognized. This means that they cannot engage in the profession they were trained for which is a common situation of keeping the migrant work force in lower positions in the European labour market. [14]

Even when migrants manage to formally arrange formal education and work in their sector, their abilities and qualifications remain devaluated.

\section{Britain and Labour Migration}

With the huge increase in demand for cheap labour in the home, employment agencies across the UK have been quick to respond. These "conditioning lives” of migrant workers further reinforce existing stereotypes of British colonization. The number of MDW's has been continuously increasing, with around 10,000 new foreign nationals arriving legally every year to work in Britain's homes. [15]

The Housekeeper Company, based in Manchester, supplies foreign housekeepers to families all over the UK: "over the last few years more and more women are juggling careers, children and the home and want to maintain high levels in all of them” — says Julia Harris from the Housekeeper Company.

The concept of immigrants as disadvantaged groups, held by British stereotypes and colonial history helps marginalize them: "British people say slavery is still happening in Africa, but they never know it's still in their own country as well” — says a MDW in a BBC report.

\section{Exploitation and abuse in the $U K$}

Many migrants put up with bad conditions because of the threat of deportation. To maintain their legal status they need a working domestic visa, naming their employer and their place of work. [10] The employer has to sign a declaration every year in order for the visa to be renewed. So, it is the worker's right to stay in this country and this depends on their boss. Migrants across Europe experience bad relationships with their employers, mainly because they often do not know their rights, and due to the uncertainty and vulnerability of their position, which allows employers to take advantage of them. The logic of constant conditioning keeps migrants on the outskirts of integration. Segmented labour markets and visa regulations (for instance diplomatic visa of no change employer) do not allow easy movement from one to the next, especially when migrant workers are tied to one specific employer.

"But with only a limited number of jobs some employers are pushing the boundaries and domestic workers are even more open to exploitation” — says the Kalayaan Centre. [15]

\section{National Legal Impediments and the UK}

Sovereignty of national jurisdiction and constitutions sometimes take precedence over international law and treaties. In theory, UK law for migrant domestic workers permits the same rights to MDWs as to any other worker. Yet there are two exceptions in the UK which discriminate against MDWs: the National Minimum Wage (NMW) and Working Time Regulation (WTR). [16] Introduced by the European Working Time Directive, as a safety measure, restrictions on the length of the work week were introduced, yet excluded "domestic servants". 
In addition, certain sections of the 1998 Working Time Regulations exclude domestic workers from rights to paid annual holidays, daily and weekly rest breaks. The 1974 Health and Safety at Work Act (HSWA) does not apply to the employment of domestic servants in a private household. Therefore Health and Safety inspectors do not have any powers to enforce provision of HSWA. Most importantly, the Overseas Domestic Worker Visa (ODWV) was dissolved in 2012. This act is an inexpensive and effective tool of protecting MDW's rights and the recent repeal possibly increases the trafficking of domestic workers through illegal routes.

Dependency on the employer remains the sole biggest problem for migrant domestic workers. National UK legislation, in particular visa registration and renewal, take away the basic rights of migrant workers. Since the reversion of the UK government back to the old ODW visa system, migrant domestic workers are treated as inferior to the rest of the working population. Working hours for domestic workers in the UK are not covered by the 48-hour restriction and an employer could legally work the individual domestic worker up to a maximum of 78 hours a week. [16] Domestic workers are exempt for paying income tax and national insurance. These taxes are required to be paid by the employer, but in reality this rarely happens. Health and safety legislation also excludes MDWs from private households. Lastly, workers are required to present itemized pay-slip documents and written statement of terms and conditions in order to renew their visa. The employer therefore has the power to withhold these documents in exchange for further exploiting the MDW. This puts the employer into a position of power over the MDW because of the necessity of visa documents, provision of health care and overall livelihood.

\section{Methodology and Data Gathering}

This research uses a mixture between empirical, qualitative research (primary data) on the one hand and existing, secondary data on the other to assess relevant measures to improve the MDWs situation in the UK. The collected data includes interviews with both experts employed by NGOs, the workers' union, charity organizations, and MDWs who in the course of their working life in the UK experienced some kind of abuse, grave mistreatment or a situation of slavery-like working conditions. The data gathered by conducting interviews has been used to learn about MDWs specific vulnerabilities as workers and to learn about new relevant aspects not covered by other scientific reports. ${ }^{2}$ [17: 35] [18: 22]

The heart of the data gathering process of this project was a several day field trip to London, UK, which took place in October 2013. In total 6 interviews with experts and 8 interviews with MDWs were conducted during that time.

All interviews realized during the course of this research project used the interview type of the Problem-Centred Interview (PCI), elaborated by Andreas Witzel and Herwig Reiter. ${ }^{3}$ [19] [20] By using this specific methodical approach, both exploration of the field (the domestic labour sector) as well as close examination of the problem (MS in the domestic labour sector) was achieved. Focussing during the interviews on the different forms of ill-treatment

2 Qualitative research methods can help to develop an understanding of certain problems and therefore can be used to detect improvements to certain situations or to develop strategies for change. The latter is the case in this research.

3 The interviews had been conducted, with minimal modifications, according to the proceeding Witzel and Reiter advise. For the analysis of the narration part of the PCI other methodological papers have been used additionally: [21: 208], [17: 66] 
allowed us to draw detailed conclusions about the main problems MDWs have to face. This knowledge together with the information provided by the experts interviewed enabled us to develop our recommendations.

\section{Key Findings}

Domestic work in UK households nowadays is often carried out by migrants. Each year a stream of about 20,000 domestic workers flows into the UK. Developed countries, such as the UK often have a high demand for a cheap, low qualified workforce to take care of tasks in households such as housekeeping, or to take care of children, disabled people or elderly family members. [22: 95] Since domestic work is usually perceived as low-level work where no special education or extraordinary skills are needed and per definition takes place in private, it is mostly hidden from public view or control, MDWs are especially vulnerable to exploitation. [23] [24: 10]

Key findings of this research harmonized and substantiated by other research findings and publications are presented in this chapter. The problems are presented thematically clustered.

\section{Broken Contracts}

The position of MDWs is weak in many ways. One of the biggest problems for them is that they have no or little chance to demand the employer fulfil their obligations fixed in the labour contract. It is a common problem for many workers that the job they have to do differs a lot from what has been arranged during the job interview or written in the job contract. [7: 14] Several times during our research we learned about the problem of the employing family assigning new tasks not agreed upon previously. These sometimes included very physical, demanding tasks, such as gardening or cleaning the premises during winter time; or tasks which are unacceptable without mutual understanding, such as taking care of disabled children or babies 24 hours a day in addition to other household chores such as cleaning, cooking and ironing. The MDWs often do not dare complain about these extra tasks because of their fear of being dismissed or ill-treated. Poinasamy points out that very often the workers lack information about their contracts and their rights: "the fact that the vast majority of domestic workers are women, adds an additional layer of vulnerability to their situation. Women in general have less access to information about their employment rights, because so many of them work part-time, and many work within private homes, giving them less sustained contact with a formal workplace, and less access to information about terms and conditions, and opportunities for training and advancement.”[22]

\section{Payment}

It is also a very common problem that employers will not pay the MDW on time. Even worse are cases where payment is completely refused. ${ }^{4}$ There seems to be the common practice among employers to pay less than agreed upon in the contract or at the job interview. In our cases the predominant share of workers is paid below the UK minimum wage. This observa-

4 In a study conducted by interviewing a total of 212 MDWs the amount of unpaid workers sums up to 3\%: [7: 17] 
tion is consistent with the results of other studies: "with regard to wages, almost no worker with whom we have spoken is paid the minimum wage.” [7: 17] According to the study conducted by the NGOs Kalayaan and Oxfam GB in 2008, 70\% of the interviewed MDWs were paid less than $£ 250$.

\section{Holidays and working hours}

Although in almost every one of our cases regulations including weekly days off and holidays were arranged, all of the interviewed MDWs had to fight for the right for free time at least once. In some cases conditions were very harsh with no time off at all. Other studies confirm this to be a common problem. According to a research conducted in 2012, the overwhelming majority of interviewed MDWs have no days off (in the job with the first employer) and no holidays at all. [16: 13]

In one of our interviewed cases, the struggle for the (promised) holidays even led to the MDW becoming redundant. In our cases it is common for MDWs to be expected to be on standby 24 hours a day. In severe cases working hours are extremely long, leaving only 4 hours of sleep a day. ${ }^{5}$

\section{Limitations of personal freedom}

From what we can deduct from our cases it seems to be common for employers to confiscate the legal documents, such as passport and visa documents, making it almost impossible for the MDW to quit the job by running away or to even leave the house. In the study conducted by Marissa Begonia in 2012 this phenomenon is very widespread: "of those migrant domestic workers employed with their $1^{\text {st }}$ employer, 26 of the employers [out of 30] with-held their passports...” [16: 16] Another method very common method to force the MDW into an obedient situation is to withhold the monthly (or weekly) payment. This makes it almost impossible, or at least very difficult for the MDW to quit the job without previous notice. The most frequent reason for the MDWs to leave their home country is the necessity to earn money to support the family back home. By withholding the payment, the MDW completely depends on the goodwill of the employer in their struggle to provide financial aid to the family. Another method of maintaining control over the MDW is to refuse to hand out payslips. It is also very common for the MDW, in certain cultural settings at least, to follow special dress codes or wear a veil. Very often it seems to be the case that this is forced upon the MDWs without their consent or even previous notice (e.g. during the job interview).

\section{Restriction of privacy}

A problem MDWs commonly have to face is the restriction or limitation of their privacy. In almost all our cases the workers have been not provided with a room for themselves at least once during their time working as MDWs in the UK. Often they have to sleep in common rooms such as the kitchen. Without a personal room most MDWs do not have a place where

5 The importance of this matter has been stressed in other research papers as well. For example: [16: 18] A statistic about working hours of MDWs is provided in the following report: [7: 17, Fig. 3] 
they can store their personal belongings or enjoy privacy. ${ }^{6}$ It also seems to be a common practice in families with small children that the MDW has to share a room with the baby or child. This is especially true in households where the MDW has to take care of the child. Another crucial limitation to a private sphere is the restriction some employers force upon the MDW of not being allowed to own a cell phone, to strictly limit the use of it, or to refuse requests of the MDW to get into contact with their relatives or friends in another way.

\section{Psychological Abuse}

Bordering these forms of mistreatment mentioned above there is the cluster of actions which can be labelled as "psychological abuse": in some cases there are reports of employers shouting at their workers or calling them names. ${ }^{7}$ During the interviews we were provided with the chance to learn about some very degrading practices some employers perform for the sole purpose of humiliation or to punish their MDWs. In one case, for example we had to learn about one very degrading practice: the employer forced the MDW to eat from a plate on the kitchen floor next to a rug where the members of the household clean their shoes.

\section{Physical Abuse and unhealthy physical treatment}

The work of MDWs have to perform sometimes has a health threatening impact. In several cases MDWs had to sleep in common rooms where they are not provided proper beds and have to sleep on the floor instead. In severe cases the worker has to perform tasks under extremely harsh conditions such as to clean the swimming pool during the winter time. Some employers do not flinch from forcing their workers to perform tasks outside or on the premises during the cold winter time, and when they are in a physically sick condition. In some cases the workers we have interviewed reported that they were provided with insufficient amounts of food, food which is not nutritious enough, or food that is of bad quality. This observation has been made by other studies as well. ${ }^{8}$ "Over 40 per cent of workers registered by Kalayaan in 2006 were not allowed regular meals. In some cases, the workers are not allowed to eat the same food as their employers, or were given very little to cook with. In other cases, the domestic worker is forced to eat the family's leftovers, a deeply humiliating experience.”[7:16]

In some severe cases physical violence by the employer against the MDW, beating or ripping out hair etc. has been reported. Another study highlights this problem as well: the level of physical abuse reported by migrant domestic workers coming to Kalayaan is shocking. A quarter reported being hit or beaten by their employers. Sometimes this would happen regularly. Or else they would be beaten as a punishment for a small mistake such as burning food, or washing clothes in a way their employer deemed inappropriate.

6 Another study illustrated this problem as well in a detailed way: [7: 16]

7 Another study illustrated this problem as well in a detailed way: [7: 16]

8 As illustrated in the following passage: "According to my survey with the 1st employer 18 (MDWs) were given food, 5 were not given any food and 7 were expected to eat leftovers and out of date food.” [16: 15] 


\section{Sexual Abuse}

From what has been reported during the interviews and from what we have learned from the expert interviews, sexual abuse is a common problem many MDWs have to face. However, it is hard to gather "hard evidence" and statistics about it, because sexual abuse is a very humiliating process and victims tend to try to hide it instead of reporting it to the police or even talking about it. Nevertheless we were able to interview one MDW who openly talked about her experience of sexual abuse by her former employer. Generalising the knowledge we gained from this case it seems that employers try to abuse their position of power they hold in over their worker. A situation where the MDW often lives in the same house with the employer might facilitate abuse: the MDW often has restricted privacy and cannot withdraw as easily. Workers living in their employers' homes are often unable to avoid sexual abuse because they do not have their own room, or if they do, they cannot lock the door. Some report having to sleep on the floor in their employer's room, again highlighting their vulnerability to sexual abuse.

\section{Connection to Trafficking in Human Beings}

Migration into the UK consists of a stream of both legal migration and illegal migration such as human smuggling and trafficking human beings (THB). THB is especially dangerous to the victim, because they usually do not obtain legal visa status, which excludes the MDW from certain rights and puts him/her into constant fear of deportation. ${ }^{9}$

MDWs often work under very bad conditions which are induced by their situation being invisible to the public or to regulatory bodies. It is the same case for trafficked workers as well; however, problems in those cases can be far more extensive. Because of the fear of losing their jobs or being deported back to their home countries, mere captivity in the place of work, or fear of punishment by the traffickers, trafficked persons have little or no means to report abusive situations to the police, or change their work place. "Whether or not a person is simply exploited financially or is the victim of trafficking may depend upon the degree to which the victim is dependent upon the employer. The term 'dependent' implies that the trafficker controls various aspects of the victim's life, including access to work, salary, housing, transportation, food, health care, contact with family and friends and free time activities.” [25: 219] Victims of THB are often trapped in their exploitative situation. This also makes it difficult for governments to intervene and help these people. This situation is nutritious soil for exploitation and abuse of trafficked persons. [24]

Consequently, there is a positive correlation between sexual work and trafficking in human beings: "traffickers recruit their victims mostly in deprived, disadvantaged or poorly integrated sectors of society, offering them employment abroad. Many victims are lured with bogus offers of legitimate employment. Others agree on the type of work they are expected to perform, but are deceived by the actual circumstances they find on arrival in the destination country. Meanwhile some victims do not even realize that they are being exploited. This is particularly the case for victims who have worked under more exploitative conditions in sectors such as agriculture or textile manufacture in their countries of origin.” [26: 23]

9 Rights a MDW with legal status aquires are sumed up here: [16: 6] 
This suggests a possible connection between domestic work and commercial sexual exploitation. MDWs are potential victims for commercial sexual exploitation such as working in unauthorized brothels or other similar establishments and forced to do so by criminal networks and organizations. This indicates that trafficked MDW might not only have to face commercial exploitation (because of harsh working conditions), but also sexual or other forms of abuse when forced to work in other fields than domestic work. There are reports that show that criminal networks, dealing with the human labor force by trafficking persons and selling them on the illegal labor market, usually tend to relocate trafficked people regularly after some days or weeks. This technique or rotation prevents the victim from establishing strong social ties and contacts that might help him/her out of their miserable situation. It might be the case that those networks do not only change the work place of the victim within one sector, say domestic labor, but also between other sectors - a person working in a household might be forced to work after some weeks in the sex business, and after some time in domestic labor again. [27: 23] To prove these hypothetical thoughts, further research is needed.

\section{Recommendations}

In this chapter knowledge about the most common problems MDWs have to face will be intertwined with information received by interviewing experts as well as literature and data from other sources to elaborate on recommendations of how to improve the situation of MDWs in the UK.

\section{Visa policy}

In the UK before 2012 domestic workers had to apply for the ODWV. This type of visa granted protection to the domestic workers and recognised them as workers covered by the protective employment law. The visa had two categories: domestic worker visa in private households; and domestic worker visa in diplomatic households. MDWs in private households were provided more rights, such as the right to change the employer. They also could apply for settlement after 5 years working continuously as a domestic worker. MDWs in diplomatic households could not change employer. This causes a single-line dependency and hierarchical inequality.

From 2012 onwards a new regulation was established in the visa system: the new type of ODWV does not contain a permit to change employer. [28] "The migrant domestic workers from third countries can only be permitted to step to the country with ODWV, this type of visa has existed since 2003. Before 1998 domestic workers could come to the UK with their existing employer, but could not change employers, and had no route to settlement in UK. This meant that those who left an abusive employer became undocumented.” [2: 5] Although the old visa system could save MDWs from this single-line dependency, Immigration Rules guarantee the worker the following beneficial things: "you and your employer should already have agreed on the conditions of your employment. You should have a copy of the conditions.” [28]

During the MDWs interviewed by us, none of them had heard of these conditions. Some report that if the employer made a contract, they do not even have a copy of it.

10 Here it says: "Domestic workers include cleaners, chauffeurs, cooks, those providing personal care for the employer or a member of the employer's family, and nannies. You must work in your employer's household in the UK.” 
The ILO Convention (No.189) mentions the point of these contracts: “each Member shall take measures to ensure that domestic workers are informed of their terms and conditions of employment in an appropriate, verifiable and easily understandable manner and preferably, where possible, through written contracts in accordance with national laws, regulations or collective agreements.” [12]

In many cases during our interviews, the MDWs mentioned that the biggest problems were and still are the visa system. It is impossible to change employer and if a domestic worker is changing his/her employer he/she becomes undocumented and has to leave the country. The most common opinions are that the old visa system should be restored in order to change this desperate situation.

\section{NGO work and legal education of MDWs}

From what we have learned during our interviews both with experts and MDWs themselves NGOs play a major role in supporting the MDWs. Often MDWs are able to escape abusive employers, dangerous situations or sleeping on the streets only with the help of specialized organisations such as Justice for Domestic Workers, Kalayaan, the Passage, Caritas Social Action Network, Unite the Union and others. Besides the hands-on-work NGOs are doing, they represent the group of MDWs, giving them a voice to be heard by the broader public and policy makers. Another important thing is that MDWs should know the language of the host country in order to fight for their rights and to turn to a legal or international organization in search of support. Some of the NGOs mentioned provide language trainings to the MDWs. In every case during our interviews it became obvious that NGOs helped to learn about legal rights and to receive help in various ways. The Immigration Rules provide legal protection: "if your employer does not meet the requirements above, you should be able to take legal action through an employment or industrial tribunal or the civil courts.” [28] It is obvious that without any English language skills and without the professional help of an NGO they will face big obstacles when turning to courts.

In order to help those NGOs in their work and therefore indirectly helping MDWs we recommend that those NGOs should be supported by government in financial terms and stronger cooperation should be realised.

\section{Media campaigning}

Modern slavery sparked the media's interest in UK after 2010. “The Anti-Slavery Day Bill” became a law in 2010. It was introduced in parliament as a "Private Members Bill” by Anthony Steen MP, for Totnes, South Devon, and passed through both Houses, unopposed although amended. The Bill defined Modern Day Slavery “... as child trafficking, forced labour, domestic servitude and trafficking for sexual exploitation.” [29] Although there were several campaigns made by major British NGOs, the biggest campaign was and still is Anti-Slavery Day, which is supported mainly by many national and international NGOs and governmental institutions. ${ }^{11}$ It is inevitably needed to put a greater spotlight on the issue of "MS", because the attention of society is important to improve the situation of MDWs. It is right to say, that

11 This campaign received the Media Award in the UK already three times, which means that the issue of slavery is in the spotlight of interest and is gaining political recognition in the UK. 
the most effective and realistic campaigns are made by the domestic workers themselves. They are included in every case and they can tell the realistic part of the situation and give examples and ideas for the political powers to make suitable decisions. It is obvious that domestic workers need to catch the broader attention of society, and that they have to represent themselves in order to stay in focus, and in order to be heard. ${ }^{12}$

The key issue of this recommendation is to support NGOs representing MDWs with financial and logistical means enabling them to campaign in a profound manner.

\section{Combating organized crime groups}

Often the domestic work market segment is fed with a labor force by organized crime groups (OCG). Of course that does not necessarily indicate that MDWs always have illegal visa status in the UK. Their status can be either illegal or legal. OCGs often lure workers into jobs with exploitative characteristics — such as long working hours and physical abuse to name but a few. OCGs conduct the transportation, smuggling or trafficking of migrants into the destination country. They also arrange the rotation of the workers within the destination country: it is common that migrant workers have to change their working position every few weeks or months, so that they cannot establish strong social ties which might help them to improve or escape their exploitative situation. Since most of the migrant domestic workers are female (and due to the OCGs poly-criminal character) there is the danger that they have from time to time to work in the sex industry, adding sexual exploitation and abuse to their history of victimization. [30: 33] [26]

To improve the situation of migrant domestic workers it is necessary to combat OCGs that specialize on disguising themselves as job agencies or au-pair-agencies. To be successful in doing so, transnational and international cooperation is inevitable. The collaboration between different national agencies (such as specialized police units) and international organizations such as the EUROPOL or INTERPOL is recommended.

Another approach to help this situation is to provide information to potential MDWs while they are still in the country of origin about the threat of organized crime. Prevention campaigns can inform the public about this issue and advise migrants to gather information before they engage the services of a job agency. It is recommended that UK based organizations collaborate with organizations or governmental bodies in the countries of origin of migrants, such as India, the Philippines or Indonesia to name but a few.

\section{National Minimum Wage}

In our interviews it became clear that almost all MDWs were promised at least once during their working life that in the UK the National Minimum Wage (NMW) would be paid by the employer who later broke that promise by paying less than the NMW. The legal problem is that MDWs, living with the employers, according to the Immigration Rules are not entitled to minimum wage. The Immigration Rules of the UK say that "if you are a member of your employer's family, live in their home and help run a family business or help with household

12 One of the most important representatives of migrant domestic workers is "Justice for Domestic Workers (J4DW)", an NGO established on March 15, 2009. It is an organisation for MDWs who work in private households in the UK. 
chores, you are not entitled to the National Minimum Wage if you share in the family's tasks and activities.” [2: 5]

So if the employer's family can prove that the employee is one of their family members, the MDWs are not entitled for the National Minimum Wage, and also the family will not pay the income taxes and national insurance for the MDWs. In reality MDWs might face difficulties proving that they are not family members, or if they are really family members they have no chance to be paid the NMW anyway.

It is a single-line dependency, the domestic worker has no possibility to move, or to earn more money and starts to depend only on her/his employer. This legal regulation therefore needs to be reviewed and changed. MDWs have under all circumstances to be guaranteed at least the NMW.

\section{Working hours and Health and Safety at Work}

"Domestic workers are not covered the by the 48-hour restriction on weekly hours and on night work set out in the Working Time Regulations.” [16: 3] Many of our interviewees (MDWs) experienced exploitative working conditions at least once. This is contradictory to what the relevant ILO Convention (No.189) mentions. [12] ${ }^{13}$

The Health and Safety at Work Act excludes MDWs from its coverage. [31] This means that MDWs are not guaranteed healthy and safe working conditions, and they could not turn to the national law to protect themselves. The ILO Convention (No.189) mentions the regulations for working conditions for MDWs. [12] ${ }^{14}$

By ratifying the ILO convention, chances are high that the unfavourable legal situation of MDWs in the UK might change and with that the general working conditions for domestic workers

\section{Conclusions}

Although formally abolished, there are forms of mistreatment of people still today, which come close to what is generally connected to the term "slavery". "Slavery-like conditions" describe best what reality is for many MDWs in the UK. Being not entitled to many rights, which are commonly granted to citizens of the UK, not covered by protective regulations of certain legal acts, many domestic workers have to face a very harsh reality. The most pressing conditions in need of improvement MDWs commonly have to face include:

- the breaking of agreements between the MDW and employer, set down in the employment agreement by the employer, with little chance for MDWs to claim their rights;

- payment which is below the NMW;

- no or vanishing few holidays and extremely long working hours;

13 The convention says: "Each Member shall take measures towards ensuring equal treatment between domestic workers and workers generally in relation to normal hours of work, overtime compensation, periods of daily and weekly rest and paid annual leave in accordance with national laws, regulations or collective agreements, taking into account the special characteristics of domestic work."

14 "Every domestic worker has the right to a safe and healthy working environment. Each Member shall take, in accordance with national laws, regulations and practice, effective measures, with due regard for the specific characteristics of domestic work, to ensure the occupational safety and health of domestic workers.” 
- limitations of personal freedom of MDWs, by removing passports, or merely confining MDWs in the house;

- restrictions of privacy by not providing a separate room to sleep in for the MDW;

- psychological abuse by shouting at the MDWs, calling them names, or other sometimes very degrading behaviour;

- physical abuse by hitting the workers, or making them eat sickening food, or threatening their physical heath in other ways;

- sexual abuse, which is hard to escape from, since it is just to assume that most sexual assaults will not be reported to police because of fear of deportation, fear of losing the job, and the non-availability to choose another employer.

We therefore recommend a change to the current visa regulations of the UK for MDWs. Currently MDWs do not have the right to change employer, and therefore to escape exploitative situations. It would also be very helpful to increase the legal status of future MDWs by lowering the barriers for working permits and visa for the UK for the domestic work sector. It should become easier and cheaper for MDWs to apply for this type of visa. Various NGOs carry out valuable work in order to support MDWs in the UK who are facing abuse and exploitation. In order to support their work, financial and logistical contribution from the governmental side is indispensable. This also enables those NGOs to campaign to obtain public awareness on that issue. Special safe houses fit for the needs of MDWs should be established where MDW receive protection, support, legal advice and temporarily a safe place to sleep. The national regulations assuring the NMW and the working hours for every worker need to be adapted to include MDWs without conditions. Additionally the UK needs to sign and ratify the ILO Convention C189 as a strong instrument in protecting MDWs in the UK from exploitation and abuse.

\section{References}

[1] BESENYŐ J.: Western Sahara. Pécs: Publikon Publishers, 2009.

[2] CLARK, N., KUMARAPPAN, L.: Turning a Blind Eye - The British state and migrant domestic workers' employment rights. London: London Metropolitan University, Working Lives Research Institute, 2011.

[3] UNESCO: Slavery Convention. Geneva, 25 ${ }^{\text {th }}$ September 1926. http://portal.unesco. org/culture/en/files/38440/12815475701Slavery_Convention_\%281926\%29.pdf/ Slavery\%2BConvention\%2B\%281926\%29.pdf (downloaded: 1512 2013)

[4] ILO: C029 - Forced Labour Convention, 1930. (No. 29) www.ilo.org/dyn/normlex/en/ f?p=1000:12100:0::NO::P12100_ILO_CODE:C029 (downloaded: 1512 2013)

[5] Office of the United Nations High Commissioner for Human Rights: Universal Declaration of Human Rights. www.ohchr.org/EN/UDHR/Documents/UDHR_Translations/eng.pdf (downloaded: 1512 2013)

[6] Anti-Slavery International: What is modern slavery? www.antislavery.org/english/slavery_ today/what_is_modern_slavery.aspx (downloaded: 1512 2013)

[7] GAVA, R., WITTENBURG, V. NIYOGI, N., ROBERTS, K.: The New Bonded Labour? The impact of proposed changes to the UK immigration system on migrant domestic workers. London: Oxfam GB \& Kalayaan, 2008. 
BOGÁRDI B., A. M. FAWCETT, J. KRIZ: Modern Slavery in the UK: Hidden Behind Silence

[8] BESENYŐ, J.: A nyugat-szaharai válság egy magyar békefenntartó szemével. Pécs: Publikon Kiadó, 2012.

[9] GUILD, E.: European Convention on the Legal Status of Migrant Workers (1977). An Analysis of its Scope and Benefits. Nijmegen: University of Nijmegen, 1999.

[10] MANTOUVALOU, V.: Modern Slavery: The UK Response. Industrial Law Journal, 394 (2010). DOI: https://doi.org/10.1093/indlaw/dwq019

[11] ILO: Declaration on Fundamental Principles and Rights at Work. www.ilo.org/declaration/ thedeclaration/textdeclaration/lang--en/index.htm (downloaded: 1512 2013)

[12] ILO: C189 - Domestic Workers Convention, 2011. (No. 189) www.ilo.org/dyn/normlex/en/ f?p=NORMLEXPUB:12100:0::NO::P12100_ILO_CODE:C189 (downloaded: 1512 2013)

[13] EU: Charter of Fundamental Rights of the European Union. Official Journal of the European Communities, (C 364/3, Article 5) www.europarl.europa.eu/charter/pdf/text_en.pdf (downloaded: 0510 2013)

[14] HUSSEIN, S., STEVENS, M., MANTHORPE, M., MORIARTY, J.: Change and Continuity: A Quantitative Investigation of Trends and Characteristics of International Social Workers in England. The British Journal of Social Work, 416 (2011). DOI: https://doi.org/10.1093/bjsw/ bcr008

[15] BBC: Dirty Work. BBS News, 2006. http://news.bbc.co.uk/2/hi/uk_news/magazine/4850602. stm (downloaded: 1512 2013)

[16] BEGONIA, M.: Migrant Domestic Workers and their Legal Struggles. Accredited Community Empowerment Course: Development and presentation of Research Skills 20112012. Africa Educational Trust \& Evelyn Oldfield Unit, 2012.

[17] FROSCHAUER, U., LUEGER, M.: Das qualitative Interview. Zur Praxis interpretative Analyse sozialer Systeme. Vienna: Facultas Verlags- und Buchhandels AG, 2003.

[18] FROSCHAUER, U., LUEGER, M.: Interpretative Sozialforschung: der Prozess. Vienna: Facultas Verlags- und Buchhandels AG, 2009.

[19] WITZEL, A., REITER, H.: The problem-centered Interview. London, Thousand Oaks, New Delhi, Singapore: SAGE Publication Limited, 2012.

[20] WITZEL, A.: Das problemzentrierte Interview. Qualitative Social Research Art, 221 (2000).

[21] SCHEIBELHOFER, E.: Combining Narration - Based Interviews with Topical Interviews: Methodological Reflections on Research Practices. International Journal of Social Research Methodology, 15 (2008).

[22] POINASAMY, K.: Protecting migrant domestic workers in the UK. Gender \& Development, 191 (2011). DOI: https://doi.org/10.1080/13552074.2011.554027

[23] BOURDIEU, K.: Die feinen Unterschiede. Kritik der gesellschaftlichen Urteilskraft. Frankfurt am Main: Suhrkamp Verlag, 1987.

[24] SKŘICÁNKOVÁ. K.: Trafficking for forced labour. UK country report. London: AntiSlavery International, 2006.

[25] ARONOWITZ, A. A.: The human trafficking-organized crime nexus. In. ALLUM, F., GILMOUR, S. (Eds.), Routledge Handbook of Transnational Organized Crime, London: Routledge, 2012. DOI: https://doi.org/10.4324/9780203698341

[26] EUROPOL: EU Organized Crime Threat Assessment 2011. The Hague: European Police Office, 2011. 
BOGÁRDI B., A. M. FAWCETT, J. KRIZ: Modern Slavery in the UK: Hidden Behind Silence

[27] ASI: Trafficking for Forced Labour in Europe. Report on a study in the UK, Ireland, the Czech Republic and Portugal. London: Anti-Slavery International, 2006.

[28] Immigration Rules. Domestic workers in private households, UKBA. www.ukba.homeoffice. gov.uk/visasimmigration/working/othercategories/domesticworkers/conditions/\#header2 (downloaded: 1512 2013)

[29] Anti-Slavery Day. www.antislaveryday.com/get-involved/organisations/ (downloaded: 1512 2013)

[30] EUROPOL: EU Serious and Organised Crime Threat Assessment. The Hague: European Police Office, 2013.

[31] Health and Safety at Work etc. Act 1974. www.legislation.gov.uk/ukpga/1974/37 (downloaded: 1512 2013) 